\section{Clinical analysis in Egypt}

SIR - Developing countries suffer from many health problems, principally because of the lack of infrastructure and old-fashioned regulations. The Egyptian journal Al Ahram published in its international edition of 28 February the health minister's promise to amend the law, restricting the clinical analysis profession to physicians only.

In the same article, the president of the medical college in Egypt added that only physicians are qualified to be clinical analysts. His first justification was longer graduate studies in medicine (one year more) than in pharmacy, but he took no account of the period of specialization of both. Second, he presented the misguided argument that in the developed countries only physicians are authorized to be clinical analysts. Such pronouncements show ignorance of the education systems in developed countries.

Law 367 (1954), which regulates this specialty in Egypt, recognizes only four specialties: medical chemistry, bacteriology, pathology and clinical pathology, and needs to updated. Changes might include (1) recognition and legislation of recent technologies such as molecular biology, genetic cytology, immunology and so on; (2) improving the quality of health professionals by extending the period of specialization to 3 or 4 years (instead of 1 or 2 years) regardless of whether they are pharmacists or physicians; (3) improving the service quality of the laboratories by external quality control; (4) including parasitology as a specialty, in a country where parasitic infections constitute a profound health problem; and (5) repealing Law 415 (1954), which prohibits specialized pharmacists from taking samples including blood and urine or even stool samples from patients for analysis according to this law, they must be taken by a physician.

Salah Abdalla

Mutualidad Mahonesa,

Mahon, Menorca,

Baleares, Spain

\section{Leprosy vaccine}

SIR - According to Bloom et al. ${ }^{1}$ the two leprosy vaccine strains, ICRC and M.w., showed identical bands in the RFLP analysis at only 2 or 3 points. But this is an understatement. The authors used two enzymes (PstI and BstElI) and two probes, $3.6 \mathrm{~kb}$ Mycobacterium leprae $65 \mathrm{kD}$ antigen and $65 \mathrm{kD}$ M.tuberculosis protein gene probe, and obtained identical bands in RFLP studies with reference to two strains in every experiment, under all four sets of conditions ${ }^{2}$. When the results are computed, it is clear that the RFLP fragments are identical at 7 bands. The authors have further studied RFLPs with two additional enzymes, EcoRI and BamHI (data not shown), implying that the results are similar. In that case the RFLP identity will be seen, at least, at four additional points. Thus, in their experiments, the authors must have observed at least 11 identical bands. Not a single different RFLP band was seen between the two vaccine strains. Further, their pattern differed completely from all other mycobacteria studies in the paper. When these observations are taken in totality, the probability that any two unrelated organisms will give such a matching pattern is extremely low.

\section{G. Deo}

Cancer Research Institute,

Parel, Bombay-400012, India

1. Bloom, B. R., Jacobs, W. R. Jr \& Clark-Curtiss, J. E. Nature 368, $579(1994)$

2. Grosskinsky, C. M., Jacobs, W. R. Jr, Clark-Curtiss, J. E. \& Bloom, B. R. Infect. Immun 57, 1535. 1535-1541, (1989).

\section{Meteoric fall}

SIR - Brown et al.'s letter and Hughes's commentary on the fall of the Peekskill meteorite (Nature 367, 624 \& 596; 1994) fail to mention one of the more fascinating aspects of the collision - namely the response of Ms Knapp's insurance company to the claim that her 1980 Chevrolet Malibu had been damaged by a $12-\mathrm{kg}$ chondritic meteorite.

Incidentally, have our actuarial colleagues been forced to recalculate the odds of a meteorite colliding with a car or, indeed, a person as a result of this one-off incident? If they haven't, it may now be time for a small wager ... or the setting up of a meteorite mutual protection insurance fund.

\section{Mark Powlson}

Medical Editorial Unit, Department of Health,

London SE1 6EF, UK

\section{Gene safety}

SIR - My reaction to the article "Error of judgement over gene safety rules" (Nature $\mathbf{3 6 7}, 49 ; 1994)$, was one of sympathy for the scientists involved. What the article did not say was that the researchers had used a replication-defective adenovirus vector expressing the SV40 large T protein. The activities of this protein have been worked on for more than 20 years and, although all the pathways for its mode of action are still unclear, a lot has been learnt. The SV40 virus expressing large $\mathrm{T}$ is semipermissive for humans and was in fact mistakenly inoculated into humans in the late 1950s during the early poliovirus and adenovirus vaccine trials. The levels of inoculated SV40 were sufficient to produce an immune response, yet no adverse effects were observed.

One can in fact work safely, according to guidelines, with titres of $10^{8}$ to $10^{10} \mathrm{pfu}$ $\mathrm{ml}^{-1}$ of SV40 on the bench. The virus is unable to produce tumours in any mammals except the hamster, and then only with large doses.

It was stated in your report that Health and Safety Executive (HSE) officials acknowledge that there was a "theoretical" risk, but the department "failed to undertake a sufficient assessment of the risk to humans". It is surprising that the adenovirus recombinant, which is unable to replicate after infection of a cell and is therefore very unlikely to recombine with an endogenous adenovirus, was thought to have the level of risk to close a laboratory. I believe the risk of infection with the virus has been assessed in the best way possible, by the inoculation of individuals with infectious virus and the use of this virus by scientists for the past 35 years. The HSE obviously thought it was time to prove its usefulness as a controlling body, but picked a very weak test case, which will make it difficult to be taken seriously when justifiable situation arises.

\section{Dennis J. McCance}

Department of Microbiology

\&Immunology, \& of Oncology,

University of Rochester,

Rochester, New York 14642, USA.

\section{Pedant mavens}

SIR - I am a regular reader of Nature and of William Safire's "On Language" columns in the New York Times Magazine. I imagine that Safire, an acknowledged language maven, would be amused to find himself credited with the coinage of the word 'maven', as he was in Christopher Longuet-Higgins book review ("The talking ape", Nature 368, 360; 1994).

While Safire is no doubt responsible for popularizing the phrase 'language maven', 'maven' is in fact Yiddish for an expert, connoisseur or judge, according to my Modern English-Yiddish, YiddishEnglish Dictionary (Uriel Weinrich, Schocken Books, New York, 1977). In common usage 'maven' frequently connotes a self-appointed know-it-all, which is apparently the sense Stephen Pinker intended when he titled one of the chapters in his recent book (The Language Instinct: How the Mind Creates Language, Morrow, 1994) "The Language Mavens" and then went on to disparage the phrase as an oxymoron.

\section{Sharon R. Seller}

Memorial Sloan-Kettering Cancer Center, 1275 York Avenue,

New York, New York 10021, USA 